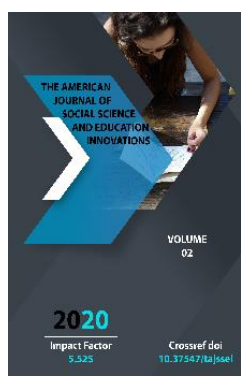

Copyright: Original content from this work may be used under the terms of the creative commons attributes 4.0 licence.

\section{Methodological Support Of Teacher Training In English Language Teacher's Development}

\author{
Shukurova Marifat Xodjiakbar Qizi \\ English As A Foreign Language Teachers At Tashkent State University Of Economics, \\ Uzbekistan
Omina Mukhiddinova Sharofiddin Qizi
English As A Foreign Language Teachers At Tashkent State University Of Economics, \\ Uzbekistan
}

\author{
Abdurakhmon Norinboev Vokhidovich \\ English As A Foreign Language Teachers At Tashkent State University Of Economics, \\ Uzbekistan
}

\title{
ABSTRACT
}

Modern English as a foreign language (EFL) teachers are required to be competent in solving problems occurred in teaching and learning processes. They should be conscious of up-to-date information about new approaches, methods and techniques, as well as, they should be capable in use of information and communication technologies (ICT) and of course should work on improvement of their language components. So that EFL teachers could succeed in those goals, they are enrolled to inservice teacher trainings (INSET).

\section{KEYWORDS}

INSET, teacher training, professional development, competence, motivation.

\section{INTRODUCTION}

English is one of the widely used language in the world. Teaching this language holds significantly important worth. As we are living in a dynamic world, teachers should be aware of all reforms in a teaching sphere. The role of
English as a foreign language (EFL) teachers is considerably essential in language achievements of the learners. Because of globalization, modernization and modifications, EFL teachers should be involved 
to develop contentious professional competence.

\section{LITERATURE REVIEW}

In the field of education, the main place is "Quality Policy" of education. High quality education is a strategic national resource, the main competitive capital, and the dynamic development of society (Tetina S.V. 2016). In modern conditions, it is required not only constant accumulation, but also updating this capital, personal personality mechanism of self-development. The purpose of continuing education is to provide opportunities for professional growth and continuing professional education, as well as to promote the development of competencies for introducing changes in practice teaching English in schools.

Underhill (1997) believes that EFL teachers have to develop themselves professionally during their teaching career because the knowledge they get about teaching in their workplace is not sufficient for them for the complete teaching process. Due to dynamic time, they might encounter new obstacles and also new ideas and concepts will be emerging in the field of teaching. So, to keep themselves abreast of the recent methodologies and trends, they have to develop themselves. Likewise, for Richards (1998), professional development demands teachers to create their own personal teaching methodology that takes into account their experience, beliefs and understanding about good teaching.

Solovyov V. considers professional development of EFL teachers as national motivational readiness for continuous professional and personal self-development, for innovative activity and professional cooperation. According to T. V. Tetina, the task of a modern English language teacher is to teach learners to study. First, the teacher needs to inculcate the need to learn from throughout life. Low motivated teachers for professional training, mastering modern educational technology are associated with a lack of independent systems for assessing the quality of their work in accordance with modern requirements. Modern requirements encourage English teachers to continuously improve their skills.

It can be said that profession of teaching require utilizing new trends and knowledge throughout the career, which leads teachers to follow continuous professional development. In this way, teachers may be able to fulfill their professional roles in the changing contexts in which teachers work and learning takes place (Wideen, Mayer-Smith, \& Moon, 1996; Day, 1999; Sandholtz, 2002).

\section{DISCUSSION}

Due to rapid changes in every phase of societies around the world, teachers' adaptations to these changes and long-term professional development have gained more attentions. As a result, it is argued that teacher professional development and continual deepening of knowledge and skills are major focus of systemic change and development in education (Ainscow, 1994; Garet, Porter, Desimone, Birman, \& Yoon, 2001). Today, in order to make knowledge economy successful, individuals and communities will constantly need to learn new things, apply their knowledge in new contexts, create new knowledge, where existing ways of doing and thinking are found wanting, and exercise wise judgment about what is important and what is not (James \& McCormic, 2009). 
EFL teacher training and teacher development are generally, taken synonymously. However, teacher training represents certain course designed for certain time duration, whereas, teacher development continues in the entire profession. However, both contribute to a teacher's improved performance. Highlighting the difference between teacher training and teacher development, Mann (2005) states that the role of English language teacher training is to introduce the methodological choices available and to familiarize trainees with that range of terms and concepts that are that 'common currency' of language teachers. On the other hand, teacher development is a continuous professional and personal growth that teachers themselves undertake and that is guided by the teachers concerned.

Some researchers suggest that professional development efforts designed to facilitate change must be practitioner specific and focus principally on day-to-day activities at the classroom level (McLaughlin, 1990 and Wise, 1991). Others indicate that an emphasis on individuals is detrimental to progress and more systemic or organizational approaches are necessary (Tye, 1998; Waugh and Punch, 1999). Many experts stress that reforms in professional development must be initiated and carried out by individual teachers and school-based personnel (Lambert, 1998; Massarella, 1990). Others emphasize the most successful programs are those guided by a clear vision that sees beyond the walls of individual classrooms, since teachers and practice-based individuals generally lack the capacity to conceive and implement worthwhile improvements on their own (Barth and Clune, 1991)

According to Ong, In-service training is the totality of educational and personal experiences that contribute toward an individual being more competent and satisfied in an assigned professional role. The primary purpose of teacher training is to enable teachers to acquire new understanding and instructional skills. It focuses on creating learning environments, which enable teachers to develop their effectiveness in the classroom (Chenari et al., 2016). According to Kazmi, Pervez and Mumtaz (2011), in-service training for teachers enables the teachers to be more systematic and logical in their teaching style. It is a planned process whereby the effectiveness of teachers collectively or individually enhanced in response to new knowledge, new ideas and changing curcumstances in order to improve, directly or indirectly the quality of pupils' education. Accordingly, the significance of in-service training should be looked in various perspectives. It promotes a very flexible environment and allow teachers to adapt with the working situation and it is also one form of motivation for employees or employers and it will continue to increase creativity in teaching process. It also enables EFL teachers to acquire new understanding and instructional skills to develop their effectiveness in the classroom (Frederick \& Stephen, 2010).

\section{RESULTS}

In-service teacher training is globally practiced with the belief that it fosters professional development of teachers. Specifically, the training has been adopted to promote continuous improvement of teaching staff, eliminate differences within the background preparation of teachers, keep the teaching profession abreast of new knowledge, enable realization of creative innovations, and facilitate teachers to tackle responsibilities associated with the changing learning 
environment (Osamwonyi, 2016; Sheth, 2004). According to Bramley (1991), in-service training is the systematic development of attitudes, knowledge, skills, and behavior patterns required by teachers to perform adequately at their given task or job.

Maduabum (1992) summarized the different forms of in-service education as follows:

Figure 2 Different forms of in-service education

\begin{tabular}{|c|c|c|}
\hline 1. & Regular courses & $\begin{array}{l}\text { These are the full time courses undertaken during the normal } \\
\text { academic session. The period of the program lasts one or two } \\
\text { months. }\end{array}$ \\
\hline 2. & Conferences & $\begin{array}{l}\text { These are academic gathering in which certain speaker come } \\
\text { prepared, often by invitation or for a fee, to open discussion on } \\
\text { some reasonably interesting or controversial theme. Generally, } \\
\text { conference attenders come to listen, ask questions for the main } \\
\text { speakers, make additional prepared or spontaneous contributions } \\
\text { to their own, evaluate opinions and points of view, and discuss } \\
\text { formally and informally among themselves. }\end{array}$ \\
\hline 3. & Workshops & $\begin{array}{l}\text { Just like conferences, workshops can be regarded as academic } \\
\text { gatherings but in this case aimed primarily at providing within the } \\
\text { intellectual horizons of participants, selected functional experiences } \\
\text { that will enhance their performance on the job. Workshops are } \\
\text { characterized by individual or group role assignments. Resources } \\
\text { persons are usually invited who come prepared and provide } \\
\text { working procedures to participants. }\end{array}$ \\
\hline 4. & Seminars & $\begin{array}{l}\text { is an academic forum whose major purpose centres on a reflection } \\
\text { or discussion of problems. It is piloted by a coordinator who has a } \\
\text { written responsibility of putting down precise or brief summary of } \\
\text { the views expressed by each member of the discussion panel. At the } \\
\text { end of the session, the coordinator presents the highlights of the } \\
\text { views expressed and invites questions, comments, observations or } \\
\text { contributions from the audience to encourage total participation. }\end{array}$ \\
\hline 5. & Exhibitions & $\begin{array}{l}\text { These can be regarded as physical displays of scientific interest } \\
\text { intended to enlighten a wider scientific community. They could be } \\
\text { of classroom application or in a broader context geared towards } \\
\text { solving societal problems e.g. making of soap or dyes from local } \\
\text { resources. }\end{array}$ \\
\hline
\end{tabular}




\section{CONCLUSION}

Teacher training is considered as being a higher priority in any nation since teachers are regarded as being sophisticated and critical, and may lead to generations' rising and development in the variety of fields. As a huge agency, education has great significance in building strong and developed communities, and the teacher is one of the primary leaders for succeeding in this. For such motives, it is always a crucial educational necessity that teachers should obtain adequate educational and professional training to possess adequate knowledge and teaching skills and to be able to dedicate themselves to the teaching process.

\section{REFERENCES}

1. https://www.elsevier.com/books/lifelo ng-education-and-the-training-ofteachers/cropley/978-0-08-023008-5

2. https://www.elsevier.com/solutions/re venue-cycle-elearning/revenue-cycleresources/revenue-cycle-blog/revenuecycle-articles/training-at-your-station

3. Mann D. The politics of training teachers in schools. In D. Mann (Ed.), Making change happen (pp. 3-18). New York: Teachers College Press, 1998.

4. McLaughlin M.W. Learning from experience: Lessons from policy. 1997.

5. Osamwonyi E. F. In-service education of teachers: Overview, problems and the way forward. Journal of Education and Practice, 7(26), 83-87, 2016.

6. Richards Jack C. and Thomas Farrell: Professional Development for Language Teachers. Cambridge University Press. 1997

7. Sheth S. Knowledge for teacher development in India: The importance of local knowledge for in-service education. International Journal of Education Development, 24, 39-52, 2004.

8. Solovyov V. Pedagogical philosophy. 2017

9. Tetina S.V. Professional competence of foreign language teacher in the conditions of adoption of teacher's professional standard. 2016

10. Underhill A. Teacher development, Its Nature and classroom observation. 1997 